Research article

Open Access

\title{
Influence of cytokine inhibitors on concentration and activity of MMP-1 and MMP-3 in disc herniation

\author{
Stéphane Genevay ${ }^{1}$, Axel Finckh¹, Françoise Mezin ${ }^{1}$, Enrico Tessitore ${ }^{2}$ and Pierre-André Guerne ${ }^{1}$
}

\author{
1Division of Rheumatology, University Hospitals of Geneva, Avenue Beau-Séjour 26, 1211 Geneva 14, Switzerland \\ 2Division of Neurosurgery, University Hospitals of Geneva, rue Gabrielle-Perret-Gentil 4, 1211 Geneva 14, Switzerland \\ Corresponding author: Stéphane Genevay, stephane.genevay@hcuge.ch
}

Received: 27 Mar 2009 Revisions requested: 13 May 2009 Revisions received: 18 Sep 2009 Accepted: 11 Nov 2009 Published: 11 Nov 2009

Arthritis Research \& Therapy 2009, 11:R169 (doi:10.1186/ar2858)

This article is online at: http://arthritis-research.com/content/11/6/R169

(C) 2009 Genevay et al.; licensee BioMed Central Ltd.

This is an open access article distributed under the terms of the Creative Commons Attribution License (http://creativecommons.org/licenses/by/2.0), which permits unrestricted use, distribution, and reproduction in any medium, provided the original work is properly cited.

\begin{abstract}
Introduction Spontaneous resorption of disc herniation (DH) after sciatica is well documented. The matrix metalloproteinases (MMP)-1 and MMP-3 are enzymes potentially involved in this process. Glucocorticoid injections are commonly used for treatment, and other anti-inflammatory molecules like tumor necrosis factor (TNF) inhibitors are under clinical investigation. However, little is known about the effect of these molecules on $\mathrm{DH}$ resorption.
\end{abstract}

Methods DH tissue was harvested from patients undergoing surgery for sciatica. Samples were thoroughly washed. Diced explants were cultured ex-vivo in 1) $0.5 \mathrm{ml}$ Dulbecco's modified Eagle's medium (DMEM) 10\% fetal calf serum (FCS), (controls), 2) recombinant interleukin 1 receptor antagonist (IL-1Ra), (100 $\mathrm{ng} / \mathrm{ml})$, 3) dexamethasone (10E-5 M), or 4) TNF inhibitor monoclonal antibody $(10 \mu \mathrm{g} / \mathrm{ml})$. Supernatants were harvested at 48 hours and frozen. Immunocapture activity assays determined total MMP activity, active MMP levels and pro-MMP levels.
Results Fourteen DH tissue samples were analysed. Levels of all forms of MMP-3 were higher than the respective levels of MMP-1 $(P<0.01)$. In particular, the median (interquartile range [IQR]) total MMP-3 level was $0.97(0.47-2.19) \mathrm{ng} / \mathrm{mg}$ of tissue compared to $0.024(0.01-0.07) \mathrm{ng} / \mathrm{mg}$ of total MMP-1 level $(P$ $<0.01)$. Incubation with IL-1Ra, dexamethasone, or TNF inhibitors significantly decreased levels of all forms of MMP-3 $(P$ $<0.05)$. Dexamethasone significantly decreased the ratio of active MMP-3 to total MMP-3 activity. A significant inhibitory effect of dexamethasone was observed only on active MMP-1, while IL-1 and TNF inhibitor had no significant effect on any form.

Conclusions MMP-3 appears to play a greater role than MMP1 in $\mathrm{DH}$ resorption. Dexamethasone, IL-1-Ra and TNF inhibitor decreased active MMP-3, indicating that the clinical use of these drugs may affect the resorption of $\mathrm{DH}$ under certain conditions.

\section{Introduction}

Disc herniation $(\mathrm{DH})$ is classically described as the protrusion of degenerated disc tissue within the spinal canal [1]. Although DH is found in many asymptomatic subjects, lumbar $\mathrm{DH}$ is associated with radicular leg pain syndrome often referred to as sciatica. While sciatica was long thought to result only from mechanical compression of the nerve root, recent studies have underlined the importance of inflammation and cytokines in this process. Partly for this reason, glucocorticoids [2] and, more recently, TNF $\alpha$ inhibitors [3,4] were introduced in the treatment of sciatica. The usual clinical evolution of sciatica is toward recovery with resolution of leg pain. Reduction in clinical symptoms has been shown to be corre- lated with a reduction of $\mathrm{DH}$ size on subsequent magnetic resonance imaging [5].

Matrix metalloproteinases (MMPs) are a group of over 20 zincdependent enzymes that catalyze the degradation of protein components of the extracellular matrix. MMPs therefore contribute to the tissue resorption and remodeling of the extracellular matrix that occur in reaction to tissue degeneration [6]. MMP-1 (collagease-1) and MMP-3 (stromelysin-1) are known to be involved in the turnover of normal tissue but also in its pathological degradation. Osteoarthritis $[7,8]$, spondyloarthropathy [9] or intervertebral disc (IVD) degeneration [10] illustrates this process. MMPs have also been shown to be 
increased in DH tissue compared with that of healthy IVDs [11] and participate in $\mathrm{DH}$ degradation and resorption after an episode of sciatica [12]. Little information is available, however, on their respective importance in this process.

Synthesized as inactive pro-zymogens, MMPs go through a post-transcriptional process of cleavage and activation, enabling the targeted degradation of their substrate. The regulation of MMP activity is a complex and finely tuned process in which both specific inhibitors (tissue inhibitors of metalloproteinases) and the regulation of afferent pathways at production and activation levels play an important part. Inflammatory cytokines such as IL-1 and TNF $\alpha$ are thought to contribute to these regulatory processes [7]. The use of glucocorticoids [2] and TNF inhibitors $[3,4]$ in the treatment of sciatica might therefore hinder $\mathrm{DH}$ resorption and, possibly, the median or long-term evolution of the disease.

The goal of the present study was therefore to investigate the effects of glucocortiocoids (dexamethasone) and specific cytokine inhibitors (IL-1Ra and anti-TNF antibody) on levels of MMP-1 and MMP-3 in DH. We used assays that distinguish active enzymes from inactive enzymes to partially address the level of regulation at which these drugs might be active.

\section{Materials and methods}

The local research ethics committee's approval was given for the work. DH tissues were obtained after informed consent from 14 patients undergoing surgical lumbar discectomy for persistent radicular symptoms. No patients had received glucocortiocoids within 2 weeks prior to surgery and none had received IL-1 or TNF inhibitors at any time.

Freshly obtained tissue samples were immediately transported in a dry environment to the laboratory, thoroughly washed with DMEM in order to remove any blood contamination, and diced into pieces of approximately $50 \mathrm{mg}$. The time duration between sample collection and processing did not exceed 1 hour. Histological analysis was performed on the first two $\mathrm{DH}$ samples. All samples were subsequently incubated ex vivo at $37^{\circ} \mathrm{C}$ for 48 hours either in $0.5 \mathrm{ml}$ DMEM supplemented with $10 \%$ FCS, in penicillin and streptomycin alone (controls), or with the addition of dexamethasone $\left(10^{-5} \mathrm{M}\right), \mathrm{IL}-1 \mathrm{Ra}(100 \mathrm{ng} /$ $\mathrm{ml}$; R\&D Systems Europe Ltd, Abingdon, Oxfordshire, UK) or anti-TNF $\alpha$ monoclonal antibodies $(10 \mathrm{ng} / \mathrm{ml}$; R\&D Systems Europe Ltd). Concentrations of anti-inflammatory molecules were chosen to match those reached in tissue in vivo after systemic administration. All tissue samples were incubated in duplicate. At the end of the incubation period, supernatants were harvested, aliquoted and stored at $-80^{\circ} \mathrm{C}$ until assays were performed.

\section{Immunocapture activity assays}

MMP-1 and MMP-3 activity assays (Amersham Biosciences, Little Chalfont, Buckinghamshire, UK) were performed accord- ing to the recommendations of the supplier. These assays measure spontaneous MMP activity (active MMP) and total MMP activity after activation (total MMP activity = spontaneously active + activatable pro-MMP; Figure 1 ), but do not capture MMP-proteinase inhibitor complexes (inactivated MMP). Total MMP, frequently referring to the sum of all three forms (pro-MMP, active MMP and inactivated MMP) because the usual immunoassays capture indistinctly all three forms at the same time, was not measured in the present study.

In the activity assay used in this study, MMP-1 or MMP-3 is captured by a specific antibody that has been immobilized on a microtiter plate. The amount of active MMP is measured directly by the incubation of the captured MMP with modified pro-urokinase (Ukcol, Amersham Biosciences), and subsequently activated Ukcol is quantified by a chromogenic substrate (S-2444, Amersham Biosciences). Color development is recorded at $405 \mathrm{~nm}$ at different time intervals. Total MMP activity (in the present study, the pro-MMP plus active MMP) is assessed through the activation of pro-MMP by preincubation with $0.5 \mathrm{mmol} / \mathrm{l} p$-aminophenylmercuric acetate for 2 hours at $37^{\circ} \mathrm{C}$ before the addition of modified Ukcol and chromogenic substrate.

The level of pro-MMP can be computed by subtracting active MMP from total MMP activity (Figure 1). Activity is expressed in recombinant enzyme equivalents in nanograms per milliliter. The lower detection limits were $1.7 \mathrm{ng} / \mathrm{ml}$ recombinant enzyme equivalents for MMP-1 and $3.75 \mathrm{ng} / \mathrm{ml}$ recombinant enzyme equivalents for MMP-3. Results were adjusted for the dry

\section{Figure 1}

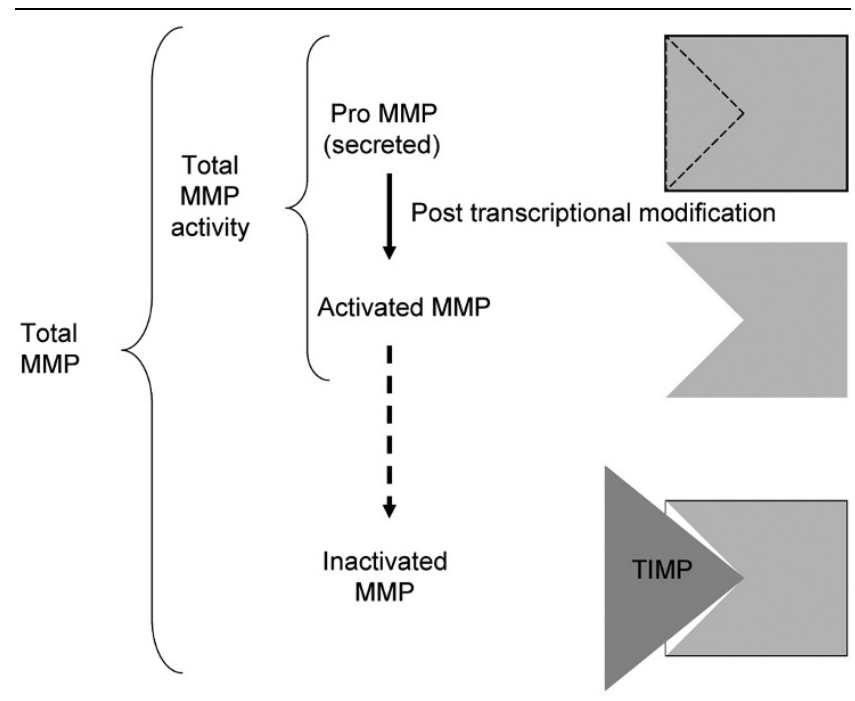

Different forms of matrix metalloproteinase enzymes and their usual nomenclature. Immunocapture activity assays (used in the present study) detect both total matrix metalloproteinase (MMP) activity and active MMP, while the standard ELISA method detects total MMP (inactive, active and inactivated forms). TIMP, tissue inhibitor of matrix metalloproteinase. 
weight of each sample and are presented as nanograms per milligrams ( $\mathrm{ng} / \mathrm{mg}$ ) of tissue.

\section{Statistical analysis}

As results were not normally distributed, they are presented as median (interquartile range (IQR)), displaying the first $(25 \%)$ and the third (75\%) quartiles. A nonparametric Wilcoxon signed rank sum test was used to compare the levels of each MMP after incubation with, respectively, IL-1Ra, dexamethasone, or TNF inhibitor with the levels of MMPs measured in the control samples. All tests were conducted at an alpha level of error of 0.05. Calculations were performed with STATA v. 9.2 for Windows (StataCorp LP, College Station TX, USA).

\section{Results}

$\mathrm{DH}$ tissue was collected during surgery from 14 patients (Table 1) operated for $\mathrm{DH}$ and sciatica unresponsive to conventional conservative treatment. Most patients had a history of chronic back pain prior to the acute episode of leg pain; two patients had already suffered from a previous episode of radiculopathy. None of them had had prior back surgery. Leg pain duration ranged from 3 to 200 weeks at the time of surgery. All patients had a positive straight leg raise sign or radicular irrita-

Table 1

\section{Baseline characteristics of the patients}

\begin{tabular}{|c|c|}
\hline & Disc herniation samples \\
\hline Sample size & 14 \\
\hline Age (years) & $45(15)$ \\
\hline Gender (\% male) & 45 \\
\hline Leg pain duration (weeks) & 14 (10 to 40$)$ \\
\hline \multicolumn{2}{|l|}{ Type of back pain } \\
\hline Acute & 5 \\
\hline Chronic & 10 \\
\hline \multicolumn{2}{|l|}{ Type of leg pain } \\
\hline First episode & 13 \\
\hline Previous episodes & 2 \\
\hline Positive nerve root irritation signa & 14 \\
\hline \multicolumn{2}{|l|}{ Neurological deficit } \\
\hline Muscle weakness & 8 \\
\hline Sensory perturbation in a dermatome & 9 \\
\hline Decrease deep tendon reflex & 5 \\
\hline \multicolumn{2}{|l|}{ Disc level } \\
\hline L3 to L4 & 2 \\
\hline L4 to L5 & 7 \\
\hline L5 to $\mathrm{S} 1$ & 6 \\
\hline
\end{tabular}

Data presented as $n$, mean (standard deviation) or median (interquartile range). aStraight leg-raising or femoral stretch. tion sign and/or a definite neurological deficit. Seven of them had a combination of two or three neurological signs. According to visual examination by the surgeons during surgery, 11 $\mathrm{DH}$ samples were subligamentous and three $\mathrm{DH}$ samples had crossed the posterior ligament.

\section{Basal matrix metalloproteinase levels}

Levels of active MMP-1 and total MMP-1 activity were analyzed in $13 \mathrm{DH}$ samples. The median (IQR) level of total MMP1 activity was $0.024(0.01$ to 0.07$) \mathrm{ng} / \mathrm{mg}$ tissue and was 0.006 ( 0 to 0.03 ) $\mathrm{ng} / \mathrm{mg}$ tissue for active MMP-1. The median (IQR) level of pro-MMP-1 was 0.01 (0.06 to 0.04$) \mathrm{ng} / \mathrm{mg}$ tissue.

Levels of active and total MMP-3 activity were analyzed in 13 $\mathrm{DH}$ samples, 11 of them being the same tissue as that used for MMP-1 level determination. The median (IQR) level for total MMP-3 activity was 0.97 (0.47 to 2.19$) \mathrm{ng} / \mathrm{mg}$ tissue and was 0.25 ( 0.17 to 0.75$) \mathrm{ng} / \mathrm{mg}$ tissue for active MMP-3. The median (IQR) level of pro-MMP-3 was 0.47 (0.19 to 1.34) ng/ mg tissue.

The median levels of total MMP-3 activity, active MMP-3 and pro-MMP-3 were found to be more than 30 times higher than those of the respective forms of MMP-1, $P<0.01$ (Figure 2). None of the clinical characteristics as displayed in Table 1, such as duration of leg pain before surgery or the extension of $\mathrm{DH}$ beyond the posterior ligament, were significantly correlated with any of the MMP-1 or MMP-3 levels.

\section{Effect of inhibitors on matrix metalloproteinases}

Incubation with dexamethasone significantly decreased the concentrations of total MMP-1 activity from 0.03 (0.01 to $0.07) \mathrm{ng} / \mathrm{mg}$ tissue to 0.004 (0.003 to 0.017$) \mathrm{ng} / \mathrm{mg}$ tissue, $P$ $=0.04$, and of active MMP-1 from 0.007 (0.0007 to 0.03) ng/ $\mathrm{mg}$ tissue to $0.001(0.0003$ to 0.003$) \mathrm{ng} / \mathrm{mg}$ tissue, $P=0.03$. Dexamethasone did not, however, affect the concentration of pro-MMP-1. Incubation with IL-1Ra, which could be analyzed in only eight samples, or with TNF inhibitor did not affect the concentration of any forms of MMP-1 (Figure 3). Addition of the anti-inflammatory drugs did not significantly modify the ratio of active MMP-1 to total MMP-1 activity.

Incubation with dexamethasone significantly decreased the concentrations of all forms of MMP-3. The total MMP-3 activity level went down from $0.9(0.4$ to 2.26$) \mathrm{ng} / \mathrm{mg}$ tissue to 0.46 (0.25 to 0.91$) \mathrm{ng} / \mathrm{mg}$ tissue, $P=0.01$, that of active MMP-3 from 0.25 (0.17 to 0.87$) \mathrm{ng} / \mathrm{mg}$ tissue to 0.09 (0.05 to 0.19 ) $\mathrm{ng} / \mathrm{mg}$ tissue, $P=0.02$, and that of computed pro-MMP-3 from 0.47 (0.19 to 1.34$) \mathrm{ng} / \mathrm{mg}$ tissue to 0.39 (0.16 to 0.72 ) $\mathrm{ng} / \mathrm{mg}$ tissue, $P=0.04$ (Figure 4).

Incubation with IL-1Ra significantly decreased the concentrations of all forms of MMP-3. The total MMP-3 activity level went down to 0.35 (0.21 to 0.7$) \mathrm{ng} / \mathrm{mg}$ tissue, $P<0.01$, that of 


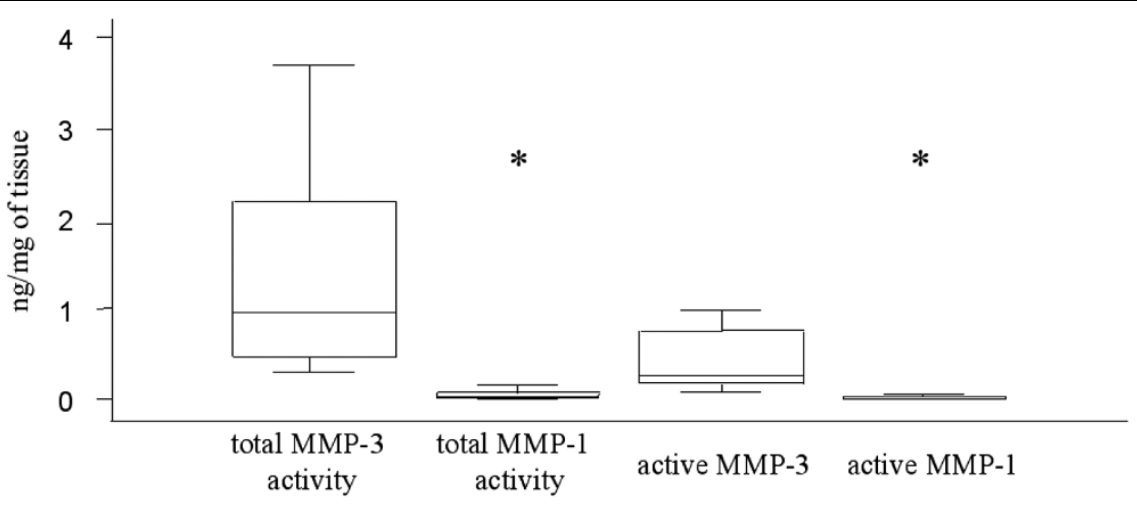

Levels of matrix metalloproteinase-3 and matrix metalloproteinase-1. Total matrix metalloproteinase (MMP)-3 activity and active MMP-3 levels were found at significantly higher levels than their respective MMP-1 form, ${ }^{\star} P<0.01$. Line in center of box, median; lower and upper borders of boxes, lower (Q1) and upper (Q3) quartiles; whiskers, minimum and maximum values; o, outliers (values exceeding $1.5 \times\left(\mathrm{Q}_{3}\right.$ - Q1)).

active MMP-3 to 0.07 (0.06 to 0.15$) \mathrm{ng} / \mathrm{mg}$ tissue, $P<0.01$, and that of computed pro-MMP-3 to 0.29 (0.13 to 0.59$) \mathrm{ng} /$ $\mathrm{mg}$ tissue, $P=0.02$ (Figure 4).

Incubation with TNF inhibitor significantly decreased the concentration of total MMP-3 activity to $0.3(0.22$ to 0.88$) \mathrm{ng} / \mathrm{mg}$ tissue, $P=0.01$, and that of active MMP-3 to 0.13 (0.53 to $0.21) \mathrm{ng} / \mathrm{mg}$ tissue, $P=0.03$. There was a nonsignificant decrease in the level of pro-MMP-3 to $0.2(0.12$ to 0.66$) \mathrm{ng} /$ $\mathrm{mg}$ tissue, $P=0.06$ (Figure 4).

The addition of dexamethasone decreased the ratio of active MMP-3 to Total MMP-3 activity from 39\% (25.6 to 53.9\%) to $20.1 \%$ (16.0 to $25.0 \%$ ), $P=0.02$, whereas no significant difference was observed with IL-1Ra and TNF inhibitor.

\section{Discussion}

In the present study, all measured forms of MMP-3 were found at higher concentrations than the corresponding forms of MMP-1, suggesting that MMP-3 plays a greater role in $\mathrm{DH}$ degradation than MMP-1. Our results inform on the process of $\mathrm{DH}$ resorption, given the known specificities of these MMPs. MMP-1 alone degrades native intact interstitial collagen molecules. MMP-3 mainly contributes to the degradation of many noncollagenous proteins, but it also breaks down previously denatured collagen fibrils [10]. The presence of both enzymes in DH tissue was previously reported [13], as was the effect of MMP-3 on DH resorption [14]. These studies, however, did not provide any information on the respective importance of MMP-1 and MMP-3 in this process. In IVD tissue, MMP-1 is expressed at a higher level than MMP-3 [12,15]. The proportion of MMP-1 decreases with advancing disc degeneration, and both enzymes are equally expressed in the most degenerative IVD [15]. Our results suggest that DH tissue resorption may be even more dependent on MMP-3 than end-stage degenerative IVD tissue. Further comparison with our study is difficult as no IVD studies reported any information on MMP levels or activity.

Each of the three drugs studied had a different effect on MMP1 and MMP-3 concentrations. IL-1Ra and TNF inhibitor only affected MMP-3 levels, whereas dexamethasone was effective in decreasing concentrations of both MMP-1 and MMP-3. To the best of our knowledge, this study is the first to report a direct effect (that is, without prior in vitro cell activation) of either IL-1Ra, TNF inhibitors or dexamethasone on the levels of MMP-1 and MMP-3 in DH tissue. Moreover, the anti-inflammatory agents' impact was observed in active components of both MMP-1 and MMP-3, suggesting that using these drugs could, at least under certain conditions, alter the speed and extent of DH resorption after an episode of sciatica. Such an effect was not reported after one foraminal injection of methylprednisolone in patients with sciatica [16], but was observed in a rabbit model using higher dosages [17]. Regarding TNF inhibitors, a single infusion of infliximab [18] showed no effect on $\mathrm{DH}$ resorption at 6-month follow-up, although resorption was observed to slow down during the first 2 weeks post infusion, compared with patients having received a placebo. This time lag coincides with the 10 days serum half-life of the drug, suggesting that repetitive infusion might affect disc resorption.

IL-1 Ra, but not TNF inhibitors, was recently reported to inhibit matrix degradation in IVD [19]. This result differs both from our findings and from a report of decreased serum levels of MMP3 in patients with spondyloarthropathy treated with TNF inhibitors [20]. A difference in tissue extracellular matrixcomposition between healthy IVD and DH tissue might account for this discrepancy. Alternatively, the immunocapture activity assay that was used in the present study specifically addresses each form of the enzyme, whereas the zymography used for the study on IVD assesses a global effect on substrate and precludes any conclusions for a specific enzyme [21]. As for dex- 
Figure 3
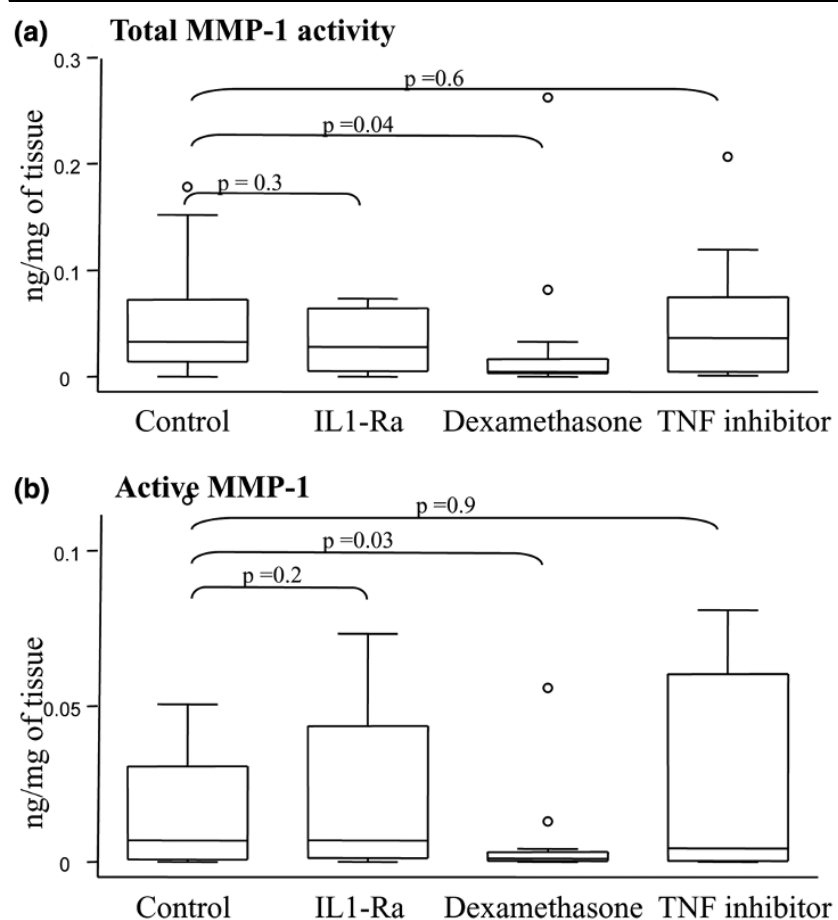

\section{(c) Pro-MMP-1}

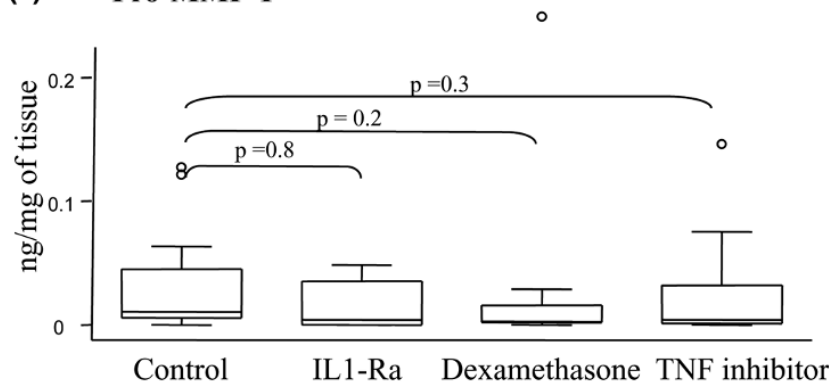

Effect of IL-1Ra, dexamethasone and TNF inhibitor on matrix metalloproteinase-1. Dexamethasone significantly inhibits both (a) total matrix metalloproteinase (MMP)-1 activity and (b) active MMP-1 without modifying levels of (c) pro-MMP-1. No effect was observed for IL-1Ra and TNF inhibitor. Line in center box, median; lower and upper borders of boxes, lower (Q1) and upper (Q3) quartiles; whiskers, minimum and maximum values; o, outliers (values exceeding $1.5 \times\left(\mathrm{Q}_{3}-\mathrm{Q} 1\right)$ ).

amethasone, no data on DH or IVD tissue are available. The inhibitory effect on MMP-3 levels, however, has been reported in chondrocytes [22] and in the serum level in rheumatoid arthritis patients after intra-articular injection of glucocorticoids [23].

Many mechanisms are involved in the regulation of active MMP levels: gene activation and repression, post-translational acetylation, DNA methylation, post-transcriptional modification of pro-MMP with complex activation of zymogens by free radicals and other enzymes, and inhibition of active MMPs by numerous molecules, including $\alpha_{2}$-macroglobulin and tissue
Figure 4
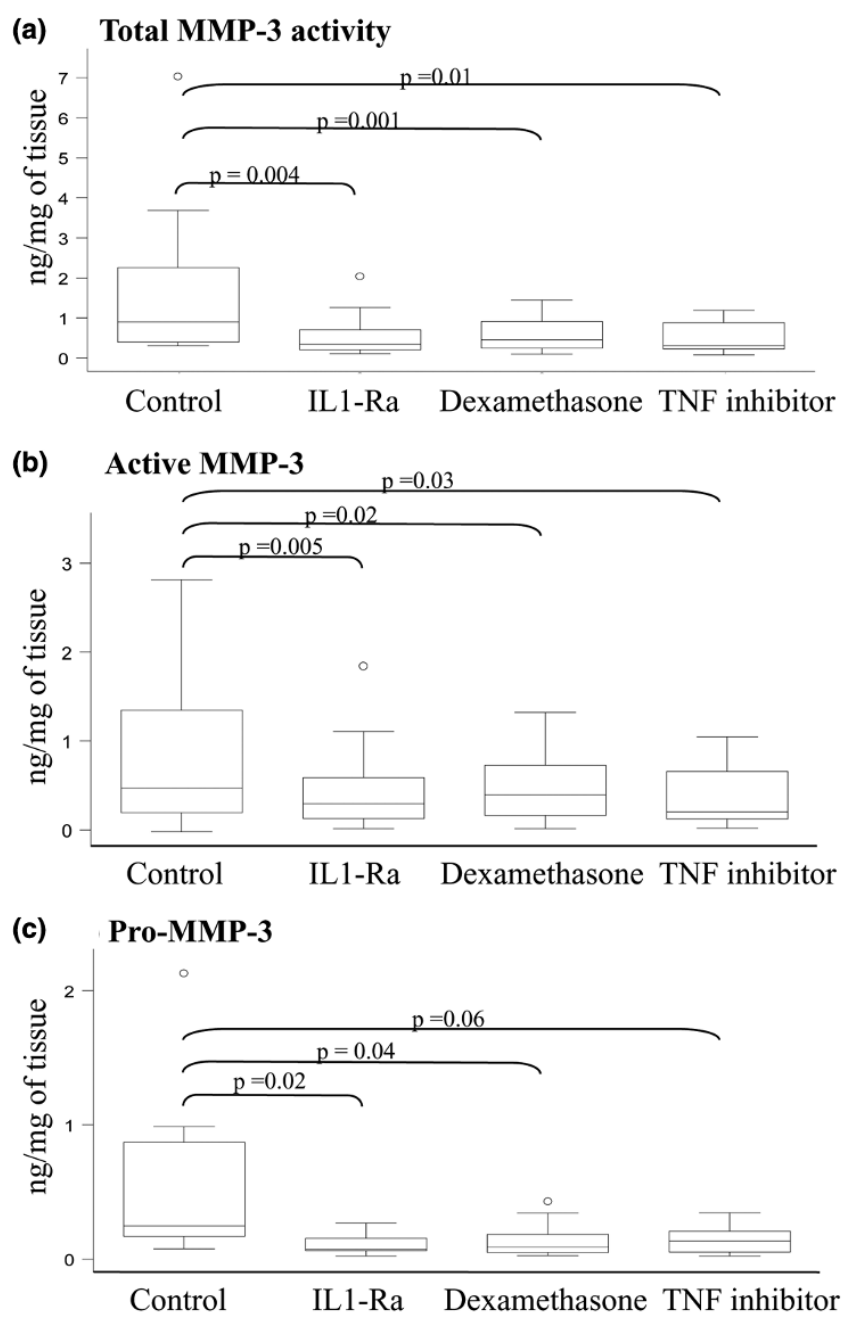

Effect of IL-1Ra, dexamethasone and TNF inhibitor on matrix metalloproteinase-3. All three inhibitors decreased levels of (a) total matrix metalloproteinase (MMP)-3 activity and (b) active MMP-3 without modifying levels of (c) pro-MMP-3. Line in center of box, median; lower and upper borders of boxes, lower (Q1) and upper (Q3) quartiles; whiskers, minimum and maximum values; o, outliers (values exceeding $1.5 \times(\mathrm{Q} 3$ - Q1)).

inhibitors of metalloproteinases. The present study was not designed to investigate these different mechanisms. The immunocapture activity assay, however, enabled the assessment of the different forms of MMPs and permits some preliminary observations. The inhibitory effect of dexamethasone on active MMP-1, without modifying the ratio between active MMP-1 and total MMP-1 activity, rather suggests an increase in inhibitory molecules. Indeed, such an effect of dexamethasone has been reported on tissue inhibitor of metalloproteinase-1 [24]. The impact of dexamethasone on pro-MMP-3 suggests an upstream effect on the pathways implicated in the synthesis of this enzyme. Because of the additional effect observed on the ratio of active MMP-3 to total MMP-3 activity, however, a more complex effect on pathways of MMP-3 regu- 
lation may be postulated. Further work is certainly needed to clarify these aspects.

The present study presents other limitations. First, the complex process of extracellular matrix regulation involves other, possibly yet unknown, enzymes in addition to MMP-1 and MMP-3. As DH tissue has not been studied in as much detail as degenerative IVD tissue, we chose to focus on what are thought to be two major MMPs, to the exclusion of less well-known molecules. Now that the results of the present study suggest that the metabolism of $\mathrm{DH}$ tissue is somewhat different from that of IVD tissue, further research is needed.

Second, for technical reasons, DH tissues had to be incubated for 48 hours, in contrast to in vivo conditions, where the effects of dexamethasone and cytokine inhibitors might be quantitatively different. We do not, however, expect this to affect qualitatively our conclusions.

The third limitation is that the in vitro conditions and the added inhibitors might also have affected cell viability. The active synthesis of MMPs in vitro speaks against large cell death, however, and the concentrations of anti-inflammatory molecules were chosen to match those reached in tissues in vivo after systemic administration.

The duration of symptoms prior to surgery varied widely and could have lead to differences in the $\mathrm{DH}$ environment. Nevertheless, statistical analysis showed that duration of symptoms was not correlated with any of the MMPs levels.

Finally, magnetic resonance imaging studies have demonstrated that the speed and degree of $\mathrm{DH}$ resorption after an episode of sciatica are related to the extension of $\mathrm{DH}$ in relation to the posterior longitudinal ligament, with transligamentous $\mathrm{DH}$ tending to shrink faster. This may be due to the quantity of granulation tissue present around the $\mathrm{DH}$. In the present study, unfortunately, only three samples of transligamentous $\mathrm{DH}$ were available, which precludes any definitive conclusion on this topic.

\section{Conclusions}

MMP-3 is present at higher levels than MMP-1 in DH, suggesting it plays a predominant role in $\mathrm{DH}$ resorption. The effect of dexamethasone and TNF inhibitors on the active forms of MMP3 suggests that, at least under certain circumstances, the clinical use of these drugs may affect the resorption of $\mathrm{DH}$. These results indicate in particular that further research on the medium and long-term evolution of $\mathrm{DH}$ size and resorption after TNF inhibitor treatment or glucocorticoid treatment is warranted.

\section{Competing interests}

The authors declare that they have no competing interests.

\section{Authors' contributions}

SG and P-AG were responsible for the study design, interpretation of the data and manuscript preparation. AF carried out the statistical analysis. ET was responsible for sample tissue collection. FM and P-AG were responsible for immunocapture activity assay. All authors reviewed and approved the final manuscript.

\section{Acknowledgements}

The authors are grateful to Pascale Sclison for her help in editing the manuscript, and to theCentre de Recherches Médicales Carlos \& Elsie de Reuter for its financial support.

\section{References}

1. Assheuer J, Schulitz K-P: Disc Herniation:Imaging. In The Lumbar Spine 3rd edition. Edited by: Herkowitz HN, Dvorak J, Bell G, Nordin M, Grob D. Lippincott Williams \& Wilkins, Philadelphia; 2004:405-426.

2. Stafford MA, Peng P, Hill DA: Sciatica: a review of history, epidemiology, pathogenesis, and the role of epidural steroid injection in management. Br J Anaesth 2007, 99:461-473.

3. Genevay S, Stingelin S, Gabay C: Efficacy of etanercept in the treatment of acute, severe sciatica: a pilot study. Ann Rheum Dis 2004, 63:1120-1123.

4. Korhonen T, Karppinen J, Paimela L, Malmivaara A, Lindgren KA, Jarvinen S, Niinimaki J, Veeger N, Seitsalo S, Hurri H: The treatment of disc herniation-induced sciatica with infliximab: results of a randomized, controlled, 3-month follow-up study. Spine 2005, 30:2724-2728.

5. Komori H, Shinomiya K, Nakai O, Yamaura I, Takeda S, Furuya K: The natural history of herniated nucleus pulposus with radiculopathy. Spine 1996, 21:225-229.

6. Flannery CR: MMPs and ADAMTSs: functional studies. Front Biosci 2006, 11:544-569.

7. Burrage PS, Mix KS, Brinckerhoff CE: Matrix metalloproteinases: role in arthritis. Front Biosci 2006, 11:529-543.

8. Close DR: Matrix metalloproteinase inhibitors in rheumatic diseases. Ann Rheum Dis 2001, 60(Suppl 3):iii62-iii67.

9. Zhu J, Yu DT: Matrix metalloproteinase expression in the spondyloarthropathies. Curr Opin Rheumatol 2006, 18:364-368.

10. Goupille $\mathrm{P}$, Jayson MI, Valat JP, Freemont AJ: Matrix metalloproteinases: the clue to intervertebral disc degeneration? Spine 1998, 23:1612-1626.

11. Haro H, Shinomiya K, Murakami S, Spengler DM: Up-regulated expression of matrilysin and neutrophil collagenase in human herniated discs. J Spinal Disord 1999, 12:245-249.

12. Weiler C, Nerlich AG, Zipperer J, Bachmeier BE, Boos N: 2002 SSE Award Competition in Basic Science: expression of major matrix metalloproteinases is associated with intervertebral disc degradation and resorption. Eur Spine J 2002, 11:308-320.

13. Matsui $Y$, Maeda $M$, Nakagami $W$, Iwata $H$ : The involvement of matrix metalloproteinases and inflammation in lumbar disc herniation. Spine 1998, 23:863-868. discussion 868.

14. Haro H, Komori H, Kato T, Hara Y, Tagawa M, Shinomiya K, Spengler DM: Experimental studies on the effects of recombinant human matrix metalloproteinases on herniated disc tissues how to facilitate the natural resorption process of herniated discs. J Orthop Res 2005, 23:412-419.

15. Le Maitre CL, Hoyland JA, Freemont AJ: Studies of human intervertebral disc cell function in a constrained in vitro tissue culture system. Spine 2004, 29:1187-1195.

16. Autio RA, Karppinen J, Kurunlahti M, Haapea M, Vanharanta $\mathrm{H}$, Tervonen O: Effect of periradicular methylprednisolone on spontaneous resorption of intervertebral disc herniations. Spine 2004, 29:1601-1607.

17. Minamide A, Tamaki T, Hashizume H, Yoshida M, Kawakami M, Hayashi N: Effects of steroid and lipopolysaccharide on spontaneous resorption of herniated intervertebral discs. An experimental study in the rabbit. Spine 1998, 23:870-876. 
18. Autio RA, Karppinen J, Niinimaki J, Ojala R, Veeger N, Korhonen T, Hurri $\mathrm{H}$, Tervonen $\mathrm{O}$ : The effect of infliximab, a monoclonal antibody against TNF-alpha, on disc herniation resorption: a randomized controlled study. Spine 2006, 31:2641-2645.

19. Hoyland JA, Le Maitre C, Freemont AJ: Investigation of the role of IL-1 and TNF in matrix degradation in the intervertebral disc. Rheumatology (Oxford) 2008, 47:809-814.

20. Klimiuk PA, Sierakowski S, Domyslawska I, Chwiecko J: Effect of repeated infliximab therapy on serum matrix metalloproteinases and tissue inhibitors of metalloproteinases in patients with rheumatoid arthritis. J Rheumato/ 2004, 31:238-242.

21. Hanemaaijer R, Visser $H$, Konttinen YT, Koolwijk P, Verheijen JH: A novel and simple immunocapture assay for determination of gelatinase-B (MMP-9) activities in biological fluids: saliva from patients with Sjogren's syndrome contain increased latent and active gelatinase-B levels. Matrix Biol 1998, 17:657-665.

22. Richardson DW, Dodge GR: Dose-dependent effects of corticosteroids on the expression of matrix-related genes in normal and cytokine-treated articular chondrocytes. Inflamm Res 2003, 52:39-49.

23. Weitoft T, Larsson A, Ronnblom L: Serum levels of sex steroid hormones and matrix metalloproteinases after intra-articular glucocorticoid treatment in female patients with rheumatoid arthritis. Ann Rheum Dis 2008, 67:422-424.

24. Forster C, Kahles T, Kietz S, Drenckhahn D: Dexamethasone induces the expression of metalloproteinase inhibitor TIMP-1 in the murine cerebral vascular endothelial cell line cEND. J Physiol 2007, 580:937-949. 